\title{
Violence against Indonesian Migrant Workers - A Causal Analysis
}

\section{Ardli Johan Kusuma, Michael Ryan York, Rizki Hari Wibowo}

Postgraduate Faculty of Politics and International Relations, Universitas Muhammadiyah

Yogyakarta

Ringroad Barat Tamantirto, Kasihan, Bantul 55183

Email:m.york529@gmail.com

Diterima pada 12 November 2014, Disetujui pada 25 Februari 2015

\begin{abstract}
Abstrak
Kekerasan dan pelanggaran terhadap buruh migran Indonesia yang tidak terlatih merajalela di Indonesia dan menjadi pelanggaran berat terhadap hak asasi manusia. Penelitian ini akan memberikan sebuah landasan untuk memahami masalah kekerasan dan penganiayaan terhadap buruh migran Indonesia di luar negeri dari sudut pandang kebijakan dan pemerintah. Isu ini akan dikaji dalam empat pendirian berbeda, pertama lembaga swadaya masyarakat, kedua, dinas pemerintah dan undang-undang yang bertujuan melindungi buruh migran Indonesia terhadap penganiayaan, ketiga, agen yang menempatkan buruh Indonesia di luar negeri, dan keempat buruh Indonesia yang telah kembali setelah bekerja di luar negeri sebagai buruh migran. Data yang bersifat kuantatif dan kualitif akan digunakan melalui pengumpulan data dan kajian statistik oleh lembaga pemerintah dan lembaga swadaya masyarakat, penilaian terhadap tren, keterangan demografis, faktor-faktor sosial yang meningkatkan risiko penganiayaan dan pembahasan tentang undang-undang terkait. Para korban, saksi, agen, dan pihak terkait akan mengabarkan keadaan yang mereka hadapi untuk menanamkan hasil penelitian ini berdasarkan pengalaman dari aktor yang berperan dalam masalah penganiayaan terhadap buruh migran. Pemahaman tentang akibat dan penyebab di balik fenomina ini sangat penting untuk membangun sebuah landasan yang dapat digunakan untuk menerapkan penyelesaian jangka panjang yang mencakupperaturan yang lebih ketat, mempereratkerjasamayang terjalin dengan negara lain, danmemberlakukan undang-undang yang akan mengatur proses perlindungan untuk tengara kerja Indonesia.

Kata Kunci: Buruh Migran, Kekerasan, Hak Asasi Manusia dan Pelanggaran Terhadapnya, Faktor Soaial dan Perumusan Kebijakan
\end{abstract}

\begin{abstract}
Violence and abuse against Indonesian unskilled labourers and migrant workers has become prolific and is a serious breach of human rights. This research will provide a basis to understanding physical violence and abuse against Indonesian migrant workers overseas from a policy and government perspective. This issue will be analyzed with four different perspectives including; non-government organizations working in the field, governments and legislation which are obliged to protect migrant workers against abuse, agents who send Indonesian migrant workers overseas and victims who have returned following employment overseas. Both quantitative and qualitative research methods will be applied through the compilation and analysis of statistics by government and non-government organizations, assessing trends, demographics and social factors that increase the risk of exploitation and also providing an overview of relevant legislation. Victims, witnesses, agents and other concerned parties will give testimony to provide primary data and greater insight into the issue. Understanding the causes and trends behind these phenomena will provide a sturdy foundation on which to build long term policy solutions and cooperation among nations. Key Words: Migrant workers, Violence, Human Right (Abuses), Trends, Social Factors, Informing Policy.
\end{abstract}

\section{INTRODUCTION}

The protection of Indonesian Migrant Workers overseas has become an issue of significant concern to the Indonesian Government and community over the past five years. Ongoing reports of acts of extreme violence and gross human rights abuses against Indonesian domestic workers have forced the Indonesian Government to work bilaterally and multilaterally with nations receiving Indonesian workers to imple- 
ment policy solutions and international agreements that will ensure the rights of workers are protected. Before any policy can be effectively implemented, a causal analysis needs to be undertaken to understand this phenomenon, ensure appropriate policy options are considered and implemented by the Indonesian Government, its regional neighbours and international partners. This analysis will provide a synopsis of the issue, statistics, the responsibilities of governments and legislation that is currently enforceable, however with significant shortcomings.

In addition to these statistics and legislation, a number of victims, agents and a nongovernment organization working within the field have provided insight into this issue at a base level. The information gathered through these sources outlines some of the major causes of abuse and violence against migrant workers. Contact with people working within the field is important to understand the realities of the industry in order to design and implement effective policy initiatives and targeted approaches. This paper aims to provide a basis for considering the proposed policy solutions as outlined in the second paper entitled 'Violence against Migrant Workers - A Policy Response'.

\section{METHODOLOGY}

In order to provide a holistic analysis, this paper presents both quantitative and qualitative research. Quantitative research will provide a statistical basis to this issue, outlining its extent, impact, trends and possible changes. As this issues if firmly grounded within a societal context, access to qualitative research through interviews and face-to-face engagement is also essential. This paper analyses this issue from four approaches, firstly, a review of current and applicable government legislation and policy, secondly, analyzing the work and findings of non-government organizations working within the field, thirdly the recounts of former workers who have returned to Indonesia following employment overseas, and fourthly, the recounts of agents who connect Indonesian migrant workers with employers and assist them to travel overseas. During the interview process with agents, they informed us that they were 'legal agents' who had been recognized and authorized by the government. The research conducted with NGOs, agents and victims was done through a series of interviews, either face-to-face or over the telephone.

Statistical information was collected from government sources and non-government organizations while written legislation as enacted by the Indonesian Government, or international treaties are available from a number of internet sources. The legislation referred to in the paper is clearly cited.

\section{RESEARCH IMPEDIMENTS}

While this paper aims to provide the most well rounded and objective analysis possible, this research is impeded by significant time constraints, limited resources and a small sample size. All the subjects are from the Java Island and therefore do not represent the length and breadth of Indonesia. This impediment is however overcome with the analysis of national statistical data. This paper presents the issues from within an Indonesian context, and provides an international perspective through analyzing Indonesia's policy and guidelines with other nations and discussing the possibility of an international dialogue to overcome this issue. Despite these impediments, this paper presents a solid statistical background and analysis, coupled with the recounts from experts within the field and people who have experienced this industry, therefore this paper remains highly valid.

\section{RESULT AND ANALYSIS}

DEFINING MIGRANT WORKERS

A number of the terms in this paper are interoperated differently across legal jurisdiction and dependent upon the nature of their employment. In line with the international legal framework, Article

1 of the Domestic Workers Convention, 2011, the term 'domestic work' is defined as work performed in or for a household or households. 'Domestic worker' means any person engaged in domestic work within an employment relationship. 'A migrant worker shall be 
defined as any person who has crossed an international border and is outside their place of origin while employed in a domestic capacity.'

As some of the legislation referred to in this paper is written and enacted in Bahasa Indonesia, the national language of Indonesia, defining the English translations and interpretations of a number of terms is important. 'Tenaga Kerja Indonesia' (TKI) or 'Indonesia's work force' shall be interpreted by this paper as people of Indonesian nationality who are undertaking employment overseas. It shall be noted that the majority of Indonesians working overseas are employed within domestic and informal industries. 'Buruh migrant' shall be translated as 'migrant labourer' or 'migrant work' and if employed in the domestic industry, a 'domestic migrant worker'. These people often work within other low paid and low skilled industries outside their country of origin. While these definitions are widely accepted, it should also be noted that there are a number of cases in which these terms are used interchangeably or with no substantial differentiation between them.

\section{INDONESIAN MIGRANT WORKERS}

The number of Indonesian citizens working overseas has increased significantly over the past decade with the domestic industry becoming an important part of the Indonesian economy and a large source of income for low income and low skilled people and their families. In December 2013, US $\$ 7.3$ billion was transferred from Indonesian migrant workers overseas to their families in Indonesia in the form or remittances, equivalent to 81.3 trillion Indonesian Rupiah (BNP2TKI, 2013). This has increased from US $\$ 6.0$ billion in 2008. It was reported in early 2013 that the number of Indonesian migrant workers reached as many as 6.5 million people across 142 nations. The figure regarding the total number of migrant workers may be misleading as the prevalence of people smuggling at illegal border crossings remains high. The movement of people across the Indonesia-Malaysia border is particularly concerning. It's therefore appropriate that the Indonesian Government makes avail- able sufficient protection to migrant workers in the case that they experience abuses, exploitation or mistreatment. Information in the form of guidelines, standard price lists for agent services and travel advice is a prudent and low cost policy for the protection of migrant workers. Indonesia is one of the largest users of social networking sites including Facebook and Twitter as forms of communication which can be used to provide information, policy, advice and warnings to Indonesian migrant workers all over the world efficiently and at low cost. This will be further discussed in part two of this paper as part of the policy recommendations. Law enforcement is also important in reducing the prevalence of criminality in this industry.

Migrant workers working in a domestic capacity overseas tend not to be stigmatized by the Indonesian community and according to IWORK, a non-government organization that works to protect migrant workers overseas; prospective migrant workers are encouraged to go overseas to gain experience and a higher income. Statistics from the National Body for the Protection and Placement of Indonesian Domestic Migrant Workers Badan Nasional Penempatan dan Pelindungan Tenaga Kerja Indonesia (BNP2TKI) shows a significant increase in the earnings of Indonesian migrant workers overseas. Indonesian migrant workers in Singapore are paid approximately $\$ 520$ Singaporean Dollars (equivalent to US\$ 415.90) per month and US\$ 447.13 in Taiwan per month. This is approximately twice to four times the wage received by an Indonesian person undertaking similar employment in Indonesia. Migrant workers may also improve their English language skills while working overseas which significantly improves their income potential upon their return to Indonesia. Prospective migrant workers are also encouraged to work abroad as their employment perspectives in Indonesia are limited, which places financial stress on their family.

Migrant workers are normally encouraged to work overseas based upon the positive experiences of others, particularly friends and family. Mr Bowo a representative from IWORK described this phenomenon as a 'domino effect'. Despite knowing the risks, they are 
still willing to work overseas based upon the higher wages, good experience and superior English language skills which they may gain overseas. This also increases their employability in other fields. It was however noted by BNP2TKI that following a series of brutal cases of abuse against Indonesian migrant workers in Saudi Arabia, the number of Indonesians applying for Saudi Arabian visas fell from 2000 per month to just 200 applications. A significant decreased that slashed the supply of Indonesian migrant workers, causing an acute shortage in supply. Indonesian workers were unwilling to take the risk of working in Saudi Arabia despite the possible benefits.

Migrant workers, during the application and preparation phase as well as during their employment overseas are vulnerable to a number of risks and in many cases ill-equipped to defend their rights against employers, agents or government agencies which are willing to exploit them.

\section{LEGAL RIGHTS OF INDONESIAN MIGRANT WORKERS}

Indonesia has a codified legal framework for the protection of Indonesian migrant workers; however its poor and inadequate application is of significant and growing concern, especially as the number of Indonesian workers overseas continues to increase and be exposed to high levels of risk. The Foreign Minister of the Republic of Indonesia is fully responsible for the protection of Indonesian migrant workers overseas. Nurus S. Mufidah, the coordinator of the advocacy network calling for the revision of proposed legislation regarding the placement and protection of Indonesian migrant workers accuses the legislation of 'not prioritizing the protection of migrant workers and making them similar to a commodity. This has the potential to continually victimize migrant workers' (Nwawai, 2013)' Legislation should be based upon the United Nations Convention on the Protection of the Rights of all Migrant Workers and Members of their Families, which was signed and ratified by Indonesia and entered into force on $1^{\text {st }}$ July 2003 however unfortunately many of the provisions have not been taken into consideration (Nwawai, 2013). This also defies international legal norms which urge nations who ratify the convention to immediately implement its protocols within domestic legal and legislative mechanisms.

Act 37, 1999 Regarding External Relations is the most important legal mechanism for the protection of the rights of Indonesian migrant workers. Article 18 of the above listed legislation emphasizes that (1) The Indonesian Government will protect the interests of its citizens or legal bodies whom face legal difficulties in foreign nations (2) Provide protection as outlined in clause (3) is to be applied in accordance with applicable laws and international norms. Foreign policy as implemented by the Indonesian Government is required to support the interests of the nation and its citizens. Article 19 notes that a Representative of the Republic of Indonesia is obliged (a) to create unity and good will among Indonesians living overseas (b) provide defence, protection and legal aid to Indonesian citizens and Indonesian legal bodies overseas in accordance with legislative guidelines, national laws and international norms. Under international law and in line with the obligations of other states, governments are required to protect their citizens and take responsibility for their actions. The government has received scathing criticism for its handling of abuse cases. Migrant workers who work overseas in any capacity are subject to Act 39, 2004 which considers the following in its perambulatory clauses;

- That work constitutes a human right which must be upheld, respected and its enforcement guaranteed,

- That each Indonesian migrant worker has rights and opportunities without discrimination, to receive employment and appropriate restitution, as a result of their work, whether within Indonesia, or overseas, in accordance with their expertise, skills, talent, interests and abilities.

- Indonesian migrant workers overseas are often made the object for human trafficking including slavery and forced work, become victims of violence, injustice and crimes against human values and dignity as well as other treatment that breaches 
human rights.

Article 4 of the above listed legislation makes unequivocally clear that the Indonesian Government is responsible for the full protection of all Indonesian citizens including migrant workers overseas in any capacity without discriminations, of any type. The government is required to provide guidance to migrant workers prior to, during and following their placement to ensure their rights are recognized and upheld.

The above listed rights and protections are administered through Work Force Attaches (Atase Tenaga Kerja - Atnaker), attached to foreign diplomatic missions of the Republic of Indonesia. Work Force Attaches have been established in 13 foreign nations where there is a significant population of migrant workers namely; Hong Kong, Malaysia, Singapore, South Korea, Brunei Darussalam, Saudi Arabia (Riyadh and Jeddah), Kuwait, Qatar, The United Arab Emirat (UEA), Taiwan, Syria, and Jordan. These attaches are responsible for providing protection to Indonesian migrant workers, in the forms outlined in Legislative Act Number 3, 2013. According to Article 5, 'the government is tasked to organize, support, undertake and oversee the placement and protection of migrant workers overseas. Article 7 outlines the obligations of the government to guarantee and rights of Indonesian migrant workers, establish and develop information systems and undertake a diplomatic effort to guarantee and effectively protect migrant workers in the receiving nation. The Act states the Government of Indonesia shall be compelled to take steps through diplomatic channels in a peaceful manner, acceptable to both parties and in accordance with determined regulations, national legislation, international law and norms.

In the case that an Indonesian migrant worker becomes the victim of violence or abuse overseas, representatives of the Indonesian Government are required to ensure the removal of the worker from the dangerous environment, ensure the worker has access to medical treatment and seek legal remedy for the breached committed by the employer upon the worker. The legal fees and any other costs will be borne by the Indonesian Government.

The legislation as tabled above outlines a robust framework for the protection of worker's rights overseas and entities them to internationally recognized rights and freedoms, however law enforcement and the application of these rights and law enforcement remain weak and underdeveloped and needs to be prioritized in any policy that aims to address this issue.

\section{LEGAL AND ILLEGAL WORKERS AND AGENTS}

There's a stark difference between legal and illegal agents working to send Indonesian migrant workers overseas, however at face value, this can be difficult to decipher. Prospective Indonesian migrant workers require an agent in order to assist them in contacting suitable employers in target countries. Legal private sector agents are those who have been recognized by the government and given the right to assist Indonesian migrant workers overseas in all capacities and are responsible for their safety and protection. The agents we spoke to said they were legal and had been recognized by the Indonesian Government. Agents often avoid and reject responsibility for the migrant worker in the case of abuse. One of the agencies we spoke to has operated for the past seven years and sent hundreds of migrant workers overseas. As tabled in Act 39, 2004 Regarding the Placement and Protection of Indonesian Migrant Workers Chapter I, Public Provisions, Article 1, Clause 5, private sector legal bodies involved in the placement of and/or provision of services to Indonesian Migrant workers must have the appropriate written licenses from the Minister to do so. As further elaborated in Chapter 5 regarding the Placement of Indonesian Migrant Workers Overseas, Article 26 states;

- Private sector agencies must be established within the context of Indonesia's legal framework

- The workers placed overseas constitute workers of the given agency

- The agency has proof of ownerships or a workplace agreement and is known to the relevant representative of the Republic of Indonesia. 
- The migrant worker has a written employment agreement

- The migrant worker is party to a social security program and/or has an insurance policy

- Migrant workers are provided an identification 'Card for Indonesian Migrant Workers' (Kartu Tenaga Kerja Luar Negeri - KTKLN)

Indonesian migrant workers are required by law to be registered and hold a KTKLN for identification purposes and so the relevant representatives of the Indonesian Government in foreign jurisdictions are aware of the workers location, status and well-being.

Unfortunately, large numbers of Indonesian migrant workers are not using legal and proper channels to seek employment overseas and place themselves in danger of serious human rights abuses, mistreatment, detention and/or prosecution. Illegal agents tend not to use official channels, nor fulfill administrative requirement and legal obligation which leaves migrant workers at risk. It is often difficult to differentiate between legitimate and illegitimate agents as its common for agents to forge documents and credentials, making them appear legal, when in fact they have not been recognized by the government. Government regulation regarding agent oversight is lacking in a number of areas. Agents that are subject to investigation often change their names, contacts and credentials and continue to operate, rarely prosecuted for abuses and breaches of responsibility. It's noted in the perambulatory clauses of national legislation Act 3, 2013 regarding the protection of Indonesian Migrant Workers that many workers are subject to human trafficking and other illegal practices. Due to the use of illegal channels, they are not appropriately documented by government agencies and circumventing a series of protective mechanism administered through embassies and work force attachés'. This leaves migrant workers vulnerable to various forms of abuse and exploitation on illegal markets and invisible to law enforcement and protection services due to the use of fraudulent passports, records and documentation. Migrant workers may not report themselves to law enforcement out of fear of punishment for the use of falsified documents or other immigration infringements.

\section{PREVENTATIVE MEASURES}

Legislation pertaining to the protection of Indonesian migrant workers does table important steps regarding the prevention of abuse through guidance and training. This is aimed at increasing the skills and capabilities of migrant workers to fulfill their job requirements as well as educate migrant workers on their rights and responsibilities. Article 39 of Act 3, 2013 states that migrant workers are required to attend a program for the development and protection of migrant workers, followed by, Article 40 of the legislation that states relevant ministries at a national, provincial and local level are obligated to provide these programs. According to the legislation, the training is required to address, mental, spiritual and physical development, improve worker discipline and personality, make available information regarding the host nation, its culture and traditions and provide workers with the relevant skills to fulfill their duties. While in consultation with migrant workers and NGOs, we were informed that workers are generally required to attend an educational program that focuses on the completion of domestic duties they are likely to perform while overseas. The agents we interviewed said that educational programs were run for a period of 2-3 months at the agency's office. A number of former workers said certificates or other forms of recognition for the completion of the course were not provided, however it's not known if these workers traveled with legal or illegal agents. The legal agents that we spoke to said they provided certificates to participants. Cultural awareness, politeness and manners, linguistic knowledge and skills in social conduct are also often not taught, or only for one month, which has the potential to causes issues regarding individual behavior while overseas and cultural isolation. The failure to adhere to social norms has the capacity to result in violence or other forms of abuse. 
Under the above mentioned ministries, information regarding arrival and departure processes must be provided, as well as information regarding the mandate and functions of national representatives and officials in their target country. Migrant workers need to be informed of their individual rights and responsibilities and the capacities of protective institutions. Migrant workers must also be informed of the conflict resolution process in the case that an issue arises and the worker is required to immediately vacate their place of work and be repatriated to Indonesia.

\section{INCAPACITY OF GOVERNMENT LEGISLATION}

Despite legislation having being enacted and reasonably comprehensive, the protection of Indonesian migrant workers is impaired by failures in law enforcement. Serious short comings are prevalent throughout the law enforcement framework which reduces its effectiveness and needs to be addressed through the implementation of thoroughly considered legislation. The Advocacy Network for the implementation of legislation for the protection of migrant workers notes the government 'does not clearly describe immigration processes and are only required to fulfill particular requirements. 'The Convention for the protection of Migrant Workers and their Families is however very detailed regarding their country of origin, their country of work, and their return journey' (Nawawi, 2013). The ambiguity of the legislation undermines its effectiveness and application in combatting this issue.

Currently enforceable legislation has been criticized for not sufficiently emphasizing the protection of

Indonesian migrant workers, leaving them vulnerable to being treated as a commodity and victimized. The Indonesian Government is consistently the target of harsh criticism for failures in the protection of Indonesian migrant workers; however experts working within this field have noted the Indonesian Government is un-authoritative and has a lax approach to this issue, placing Indonesian migrant workers at serious risk.

\section{CAUSES OF VIOLENCE AGAINST INDONESIAN MIGRANT WORKERS}

Understanding the causes of abuse is an important aspect in implementing appropriate policy solutions. This analysis was gathered through interviews with a number of stake holders including agents, victims, former migrant workers and an Indonesian nongovernment organization called IWORK, working to protect migrant workers. The following are considered major causes of violence against migrant worker.

\section{LACKING GOVERNMENT RESPONSE}

The government's response and capacity to deal with this issue is central to its prevention. While discussing this issue with a representative of IWORK, he noted that the most prominent reason that Indonesian migrant workers are victimized and abused overseas is as a result of the Indonesian Government's lacking wiliness to appropriately deal with the issue. During the course of this discussion he noted, that The Philippines have a significantly higher number of migrant workers overseas working in the domestic and housekeeping industry, however the number of cases of abuse against Indonesian workers is much higher than cases of abuse against Pilipino workers. Research undertaken by this organization noted that Indonesian workers do not have inferior skills or capacity to undertake domestic work overseas and in some cases, they were better equipped to do so then their Pilipino counterparts, however the number cases of violence against Indonesian migrant workers is still significantly higher. The superior English language skills of Filipino migrant workers may be considered a factor in increasing communication and reducing violence.

IWORK has however equated this phenomenon to the difference in government policy and response to cases of abuse. The Filipino Government has a much stronger policy stance against abuses and ensures the offending party is appropriately and swiftly dealt with through legal channels. In a number of cases, the president has become directly and personally involved, demanding the victim be released into the protection of the President and given passage to immediately 
return to The Philippines. Indonesia does not follow such assertive policy and in a number of cases, the Indonesian Government has been harshly criticized for its lacking and late response. Indonesia is one of the world's largest sending nations of migrant workers and following eight years since the ratification and recognition of the Convention for the Protection of Migrant Workers and their Families, all articles in the convention have still not been implement. 'This is significantly longer than other sending nations with The Pilipino Government taking only two years, Bangladesh and Argentina taking three years and Peru taking one' (Syahputra, 2013).This has placed both domestic and international pressure on the government to act. It's perceived that the consequences of abuse against Indonesian migrant workers are significantly less than the consequences for abuses against Filipino workers.

Other issues regarding corruption and collusion within Indonesia's embassies and law enforcement agencies has undermined the authority of the Indonesian Government and its ability to deal with and prevent violence and ensure offending parties are appropriately investigated and sentenced. Representation is a major issue and while Indonesia dispatches qualified and competent diplomats, it's noted that their attitude and sense of urgency toward the issue of migrant worker protection seems lacking, directly impacting their capacity to appropriately combat this issue. In 2013, the Saudi Government offered free amnesty to foreign low skilled migrants living on expired or false documents. There were over 80,000 Indonesians who applied for the amnesty however only 10,000 were successfully granted amnesty in the given timeframe. This is one such example of the Indonesian Government's inability to deal with and adequately represent the sheer number of Indonesian migrant workers overseas.

\section{MISUNDERSTOOD RESPONSIBILITIES OF AGENTS}

Secondly, the manner in which Indonesian migrant workers are prepared and sent overseas is concerning and places these people at risk of abuse without the facilities or capacity to seek assistance. Agents either do not have the capacity, or are unaware of their responsibilities in the process of sending Indonesian migrant workers overseas. IWORK described them as facilitators, assisting the worker to find employment overseas, however in the case of abuse, they immediately deny any responsibility and take no further action. Proposed laws regarding the protection and placement of Indonesian migrant workers does not follow the clearly defined responsibilities of relevant stakeholders. As previously noted, agents are required to assist in facilitating the preparation of prospective workers including their recruitment, placement and provide ongoing oversight while overseas to ensure cases of abuse are swiftly reported and dealt with. The Commission for the Elimination of Discrimination Against Women (CEDAW) has urged the government to take similar steps in the process of oversight and monitoring possible cases of violence. Agents promote migrant workers like businesses promote products, through print media, radio and pamphlets in the target country. According to the agents that contributed to this research, they earn approximately two million Indonesian Rupiah, equivalent to USD170.72, for securing a placement for one worker. This is a substantial amount of money in Indonesia.

One of the most prominent reasons that violence is not detected and reported is workers are sent illegally or with misleading and false information. We were informed by an NGO that during the preparation process prior to the worker being placed overseas, the employer is provided a number of profiles for possible workers that may be suitable to meet their needs. In the case that a single migrant worker is selected by two different employers, often the selected worker is sent to one of the employers, while another worker, possibly without the required skills however using the same information, credentials and identity is sent to the second employer. Documents are then falsified and the worker is sent using the assumed identity. In the government's legislation, the proses of recruitment, enrolment and selection is mention, however the designation of responsibilities is unclear (Nawawi, 
2013). This places the worker at a significant risk of violence as they circumvent proper legal protocols both in Indonesia and overseas while traveling on false documents and they do not have the skills required as required by the employer and guaranteed by the agent. This can cause frustrations and led to violence, mistreatment, refusal to pay wages, exploitation in other ways, including prostitution or termination of employment in which the Indonesian migrant worker is left stranded in a foreign nation.

This process breaches Indonesian law as well as the laws of their target country. The minimum required age for migrant workers in Saudi Arabia is 21, however there are a number of cases in which 17 year old girls have been sent with falsified documents and assumed identities. The age of the girls was however unknown until issues arose. This has a number of legal ramifications in the case of an incident, insurance and other legal proceedings, as well as documentation, statistics and oversight by Indonesian Embassies. This inhibits their capacity to provide sufficient and efficient protection to Indonesian migrant workers overseas. In addition to this, workers arrive at their place of employment with skills that are incompatible with the requirements of their employer and inconsistent with those listed on their worker profile. This results in frustration and has the potential to causes violence and other abuses, including the refusal to pay the worker's wages.

\section{ILLEGAL AGENTS}

Illegal agents are a significant concern that needs to be overcome with government legislation and regulation. Agents recruit and send a significant proportion of Indonesian migrant workers overseas and crime or abuse against these workers is often not reported due to fear of authority, or their illegal statues in the country. Therefore official statistics can be significantly underestimated and misleading. Indonesian migrant workers are either smuggled across borders particularly between Indonesia and Malaysia, or Indonesia and Singapore. The illegal smuggling of migrant workers in Saudi Arabia and Middle Eastern countries occurs as a result of people undertaking activities incompatible with their visa conditions or overstaying their time of legal residence in the given country.

These agents demand the payment of extortionate fees that are not disclosed upfront and may be taken directly from the income of the individual worker. They are often unable to lodge complaints against agents that charge excessive fees or engage in other forms of financial exploitation. According to the agents we spoke to, prospective migrant workers are charged between 10-15 million Indonesian Rupiah, equivalent to US\$ 853.61-1280.41, which places the worker in debt before they have departed. This significantly reduces the income and financial security of migrant workers to the extent that they are often unable to pay visa costs, agent charges and other living costs and unable to leave abusive and violent employers. Upon receiving their wage, the money is handed, usually in cash to their contact person, in their country of employment, who sends the money to their agent in Indonesia, who then provides the money to the worker's family. During this process, money may be stolen or incorrectly recorded to which migrant workers have little capacity to prevent this or lodge an official complaint against corruption.

Illegal agents are neither regulated nor overseen by government and often change their names and contacts in the case that the government does start to investigate possible illegal conduct. This makes them extremely difficult to prosecute and the government seems to show a lacking willingness to tackle this issue. Agents are not required to register as official organizations or companies allowing them to circumvent legal obligations and disguise illegal conduct and unethical business process.

\section{FRAUDULENT DOCUMENTS}

Fraudulent documents do not necessarily cause violence, however are a major hindrance in the government's effort to combat violence. There are a number of ways in which passports and documents regarding experience, previous employment, education, personal details etc. are falsified in a manner that 
places these people in vulnerable and dangerous situations which cannot be easily resolved, even with consular assistance. Migrants are also reluctant to approach law enforcement at the risk of being detained for breaches to immigration law. The Indonesian bureaucracy for the acquisition of a passport and other identification documents is relatively lax and people are easily able to obtain these documents with false names. Cross-checking and other verification processes are not enforced. This causes issues that are further complicated if the migrant worker is unable to communicate in the local language and adhere to cultural norms which has the potential to result in violence. In the case that violence does occur, the Indonesian Governments encounters difficulties in locating and contacting the individual worker due to false identification and personal credentials and the fear of punishment and/or other financial penalty.

\section{PROVISION OF SKILLS, LANGUAGE AND CULTURAL KNOWLEDGE}

As noted above, legislation requires perspective Indonesian migrant workers to be given the skills required to undertake their function while overseas. This is done through training and education centers, however is unfortunately insufficient, resulting in the sending of ill-equipped migrant workers who lack the skills needed to appropriately fulfill they job description and communicate in order to acquire the required skills. This reduces the effectiveness of these workers overseas, which causes frustration among their employers and results in violence. In addition to this, these migrant workers are often not given the cultural and linguistic skills required to appropriately conduct themselves in foreign nations. Norms of politeness, respect and social conduct often vary in different cultural contexts and this causes issues when these norms are not adhered to or appropriately understood.

\section{LACK OF EXTERNAL SUPPORT AND INFORMATION}

Migrant workers have the right to be supported and protected while overseas. Despite this guarantee, when an issue arises, they are often abandoned by their agents, especially if the agent is illegal and not registered by the Indonesian Government. This makes it extremely difficult for them to contact authorities or the embassy and request assistance. Illegitimate agents also financially exploit these workers by charging excessive and ongoing fees for services, pushing them into debt which cannot be paid off with their wages and inhibiting their financial independence. Information is difficult to attain and the flow of external information to migrant workers can be restricted by their employer in some countries. This is particularly concerning in Saudi Arabia and other Middle Eastern nations, however has improved in parts of Asia.

\section{CONCLUSION}

Violence, exploitation and human rights abuses pose a serious threat to the lives and wellbeing of Indonesian low-skill and domestic workers overseas. In recent months, the media has exposed a series of brutal cases of torture and violence against Indonesian workers which has caused a resurgence in concern for the issue. Indonesia has a large and increasing number of migrant workers overseas which is placing pressure on the government to act and implement regulation and policy capable of addressing these issues of abuse. Migrant workers are entitled to full human rights protection as outlined in Indonesia's Constitution and other human rights legislation. International organizations for the protection of human rights and working conditions have urged the Indonesian Government to act upon cases of abuse against its citizens overseas. Throughout the course of this research, a number of major causes can be identified that trigger this form of violence or inhibit the government's capacity to prevent it. The government's lacking response and seemingly poor attitude towards the issues is identified as a major factor that must be rectified. The government needs to work proactively across ministries, departments and nations to effectively address this issue. There is also a lacking awareness be agents and other parties facilitating migrant workers regarding, rights, responsibilities and proce- 
dures in the case of abuse or other ill treatment. Failure in the provision of information, knowledge and skills decreases the effectiveness of these workers, increases the frustration of their employers and has the capacity to trigger violence. Workers often lack the required knowledge regarding their rights as codified in Indonesian legislation, their government's responsibilities and international human rights frameworks. Workers are therefore unable to seek assistance or protect themselves if they fall victim to abuse. Understanding these contributing factors and causes is pivotal to the effective formulation and implementation of policy tailored to this particular phenomenon to provide appropriate legal remedy to victims and protect future prospective migrant workers. The second paper entitled Violence against Indonesian Migrant Workers - A Policy

Response will further discuss an appropriate and multi-faceted policy response to address this issue.

\section{BIBLIOGRAPHY}

Antara, 2014. Warga Desa Myanmar, Sasaran Empuk Penyelundup Manusia. Myanmar's Rural Dwellers, a Soft Target for People Smugglers. (Translation from Indonesian). Published 31 July 2013. Available at

Association of South East Asian Nations Charter. 2008. Charter of the Association of Southeast Asian Nations. Entered into force on 15 December 2008. Available at http://www.asean.org/archive/ publications/ASEAN-Charter.pdf

BNP2TKI, 2013. Remitansi TKI Tahun 2013 Capai Rp 81,34 Trilyun (Remittance of Indonesian Migrant Workers in 2013 Reaches Rp 81,34 Trillion. 22 December 2013. Available at: http:// www.bnp2tki.go.id/berita-mainmenu-231/9227-remitansi-tkitahun-2013-capai-rp8134-trilyun.html

BNP2TKI Badan Nasional Penempatan dan Pelindungan Tenaga Kerja Indonesia - National Body for the Placement and Protection of Migrant Workers, 2014. Pemerintah Berlakukan Perjanjian Kerja TKI dengan Arab Saudi. Government Implements an Work Agreement for Indonesian Domestic Workers with Saudi Arabia. Published on the $9^{\text {th }}$ March 2011. Available at: www.bup2tki.go.id/ berita-mainmenu-231/4123-pemerintah-berlakukan-perjanjiankerjatki-dengan-arab-saudi.html.

Indonesian Government, 2002. Ratification International Labour Organization Convention no. 88 Concerning the Organization of the Employment Service(konvensi ilo no. 88 mengenai lembaga pelayana penempatan tenaga kerja). Act 36, 2002. Legislative Assembly of the Republic Of Indonesia, Jakarta

Indonesian Government, 2013. Act Number 3, Year 2013 Regarding the Protection of the Indonesian Work Force Overseas. Legislative Assembly of the Republic Of Indonesia, Jakarta
International Labour Organization, 2013. Qualitative research on Employment Relationship and Working Conditions. Preliminary Guidelines. Tools for researching domestic work: Geneva. Available at http://www.ilo.org/wcmsp5/groups/public/_ed_protect/— protrav/-travail/documents/publication/wcms 248899.pdf

Pécoud, 2009. Migration and Human Rights. The United Nations Convention on Migrant Worker's Rights. UNESCO Publishing: New York.

Republik Indonesia, 1945. Undang-Undang Dasar Negara Republik Indonesia Tahun 1945.

Constitution of the State of the Republic of Indonesia, 1945. Jakarta

Nawawi, 2013. Rancangan Undang-Undang Masih Abaikan Pelindungan TKI Proposes Legislation Still Ignores the Protection of Migrant Workers. Universitas Islam Indonesia.

http://pusdiklat.law.uii.ac.id/index.php/Berita-Harian/RUU-PPTKLNMasih-AbaikanPerlindungan-TKl.html

Republic of Indonesia. 2009. Protocol Against the Smuggling of Migrants by Land, Sea and Air,

Supplementing the United Nations Convention Against Transnational Organized Crime. Jakarta. Available at: http://hukum.unsrat.ac.id/ uu/uu_15 2009.pdf

Syahputra, E. 2013 Penyebab Indonesia Meratifikasi Konvensi PBB 1990 Tentang Perlindungan Hak Buruh Migran Beserta Anggota Keluarga. Cause for Indonesia's Ratification of the United Nation's 1990 Convention Regarding the Protection of the Rights of Migrant Workers

Including their Families. Jurnal Analisis Hubungan Internasional Journal for the Analysis of

International Relations. Vol.2 / No.2 pp. 177-192. Available at: http://www.google.com.au/ url? sa $=\mathrm{t} \& \mathrm{rct}=\mathrm{j} \& \mathrm{q}=\& \mathrm{esrc}=\mathrm{s} \& \mathrm{frm}=1 \&$ source

$=$ web\&cd $=1 \&$ ved $=0 C$

BwQFAA\&url=http\%3A\%2F\%2Fjoumal.unair.acid\%2FfflerPDF\%2FJumal.doc\&\&ei=omu U8f0AcG48gXyjYC4Dg\&usg=AFQjCNFy322uTSaAnkHI3Cf2-LLBRmuew 